\title{
Does government spending affect income inequality? A meta-regression analysis
}

\begin{abstract}
In this paper findings of a meta-regression analysis are presented exploring the effects of government spending on income inequality, with a particular focus on low and middle income countries. We identify a total of 84 separate studies containing over 900 estimates of the effect of one or more measures of spending on one or more measures of income inequality. The results show some evidence of a moderate negative relationship between government spending and income inequality, which is strongest for social welfare and other social spending, and when using the Gini coefficient or the top income share as the measure of inequality. However, both the size and direction of the estimated relationship between government spending and income inequality is affected by a range of other factors, including the control variables and estimation method used. We also find evidence of publication bias, in that negative estimates of the relationship appear to be under-reported in the literature.
\end{abstract}

Keywords: Income Inequality, Government Spending, Meta-regression 


\section{Introduction}

The issue of inequality has been a key issue in international development for several decades now. Since the 1970s, a large literature has emerged which documents the many adverse effects of inequality on socio-economic outcomes, including investment and economic growth, poverty, health and well-being, crime, conflict and social cohesion - see for example Easterlin (1974), Williams (1984), Alesina and Perotti (1996), Ravallion (1997), Barber (2001), Luttmer (2005), Eibner and William (2005), Veenstra (2005), Subramanian and Kakawi (2006), Clark et al (2008), Gravelle and Sutton (2009), Wilkinson and Pickett (2009), Stiglitz (2013) and Ostry et al (2014). In addition, all societies share a basic, intrinsic concern for equity and justice, and high levels of inequality often conflict with those notions - as for example when life chances or opportunities differ significantly between groups defined by gender, inherited wealth, ethnicity or other accidents of birth (World Bank 2005).

Widespread concern about the adverse impacts of income inequality has generated significant interest in the question of what governments can do to reduce inequality. The sorts of government policies which can affect income inequality are recognised to be broad, including fiscal policy, trade policy, minimum wages, interest rate controls, land reform, anti-discrimination legislation, affirmative action, and so on. Nevertheless, choices with regard to the level and composition of government spending are clearly one important way of addressing income inequality, and a large body of literature has emerged which investigates the effects of government spending on income inequality, much of it using cross-country econometrics.

In this paper we present the findings of a meta-regression analysis exploring the effects of government spending on income inequality, with a focus on low and middle income countries. ${ }^{i}$ We examine the results from the econometric literature, and identify a total of 84 separate studies containing over 900 estimates of the effect of a measure of spending on a measure of income inequality. We follow the MAER-Net reporting guidelines (Stanley et al, 2013:393) and adopt the following structure. The next section provides a review of the literature summarising the key evidence relating to the effects of government spending on income inequality in low and middle income countries. Section 3 outlines the search strategy and inclusion criteria; section 4 presents and discusses the meta-regression approach as well as findings. Section 5 concludes this paper.

\section{Literature Review}

There is much evidence to suggest that at least some types of government spending have tended to lower income inequality in many countries and regions of the world (e.g. Goni et al 2011; Lustig 2011, 2015; Lustig et al 2013; Martinez Vazquez et al 2012). However, it is also recognised that the relationship between government spending and inequality is complex, and many doubts have been raised about the effectiveness of government spending as a redistributive policy instrument, particularly in low and middle income countries.

For example, it is often argued that government spending on social transfers tends to reduce income inequality, but the size of the effect can vary substantially, depending on the extent to which transfers are targeted on lower income groups. If most spending on transfers are captured by the middle class, for political economy reasons, the impact on inequality may be quite small (Milanovic 
1994). The same applies to spending on indirect subsidies, which makes up a significant share of total government spending in many developing countries, but which often disproportionately benefits higher income groups (Rhee et al 2014). It has also been argued that government spending on health and education reduces income inequality, by producing a more equal distribution of human capital. However, the size of the effect again depends on how well such spending is targeted. There is evidence that much of the benefits of government health and education spending in developing countries are received by middle-income groups in urban areas (Tanzi 1974, Alesina 1998, Davoodi et al 2003).

One key issue in assessing the effects of government spending on income inequality is the distinction between 'first-round' and 'second-round' effects (Chu et al 2000; Bastagli et al 2012, 2015). For example, the immediate first-round effect of government transfers to lower income households will be to reduce inequality in household disposable (post-fiscal) income, since transfers are included in the definition of disposable income. Over time however, transfers can also have second-round effects on inequality in household market (pre-fiscal) income, which may either reinforce or offset the first-round effects. Government consumption spending, which does not include transfers or indirect subsidies, can still have significant second-round effects, although some such spending, for example on primary education, may affect income inequality only after a fairly long time lag (ibid). The overall effects of government spending may differ therefore, depending on how income is measured (post-fiscal or pre-fiscal), and on the time period being considered.

In addition, both spending and the financing of spending can affect income inequality, and the two effects could either reinforce or counteract each other. It is often argued that the redistributive effect of taxation in developing countries has been limited, due for example to greater reliance on indirect taxes and widespread evasion of direct taxes (e.g. Tanzi 1974, Bird and Zolt 2005, Chu et al 2000, Goni et al 2011, Mahon 2012, Claus et al 2012). However, there is evidence that higher inflation raises income inequality (e.g. Bulif 1998, Easterly and Fischer 1998), which would offset the redistributive impact of government spending if the latter is financed via monetary expansion. From an empirical point of view therefore, the estimated effects of government spending may differ depending on whether we are referring to the 'overall' effect of spending, including the way in which it is financed, or the 'pure' effect, controlling for the way in which it is financed.

Another important issue is reverse causality. It has been argued that countries with higher levels of inequality in market income tend to engage in more redistributive activity (Meltzer and Richard 1981, Alesina and Rodrik 1994, Persson and Tabellini 1994). The idea is that when market incomes are unequal, governments face political pressures to redistribute income. In a democratic system for example, a larger share of the population will stand to gain from income taxes and transfers, and a political majority emerges in favour of redistribution. Even in a non-democratic system, similar processes may operate, e.g. through popular mass protest in support of redistributive political movements. ${ }^{\text {ii }}$ Thus the direction of causality between government spending and income inequality can run in both directions, and unless controlled for in some way, this could result in biased estimates of the causal impact of government spending on income inequality.

Despite widespread interest in the effects of government spending on income inequality, the results from the econometric literature appear so far to be inconclusive. iii One widely cited study (Dollar and Kraay 2002) using a large cross-country dataset found no evidence of a statistically significant 
relationship between government spending on health and education and the share of the poorest 20 percent of households in national income, which is one common measure of income inequality. A recent update of this study, by Dollar et al (2013), found similar results. However, other recent studies have found evidence that certain types of government spending, for example on social welfare, education and health, do have a negative and statistically significant effect on income inequality (e.g. Martinez Vazquez et al 2012, Claus et al 2012).

There does therefore appear to be a role for meta-regression analysis in terms of synthesising these apparently conflicting research findings from the econometric literature, and in explaining why estimates of the effect of government spending on income inequality do tend to vary. There has to our knowledge been only one systematic review of the evidence on the determinants of income inequality. This is the study by Abdullah et al (2015), which compares the results of 64 mainly crosscountry econometric studies looking at the effects of education on income inequality. ${ }^{i v}$ Their analysis showed that indicators of education do on average have a negative effect on income inequality, and that the heterogeneity of results can be explained - via meta-regression analysis - by a combination of differences in econometric specification, and differences in measures of inequality and education. 


\section{Search Strategy and Inclusion Criteria}

\section{Search strategy ${ }^{v}$}

In order to select appropriate databases for this review we followed the Campbell Collaboration guide on key online databases for systematic reviews in International Development (Campbell Collaboration 2012). This list was complemented with additional databases and websites used by other systematic reviews on questions relevant to this review. We also reviewed relevant institutional websites of key institutions and conference proceedings (see Online Appendix, Table A1.1. for details). Each database was searched using a combination of the search terms indicated in Table 1. This shows three sets of concepts (A, B and C), each of them containing a list of associated terms or synonyms that were used in our search. When using foreign language databases, each of the terms was translated into the appropriate language, i.e., Portuguese or Spanish. Due to the fact that some search engines only allow a limited number of operators, two search query strings were used: a long version and a short version. The long version follows the equation:

$A+(B W / n C)$

Thus the terms within columns A, B or C in Table 1 were combined with 'OR'; columns B and C were combined with the proximity operator $W / n$, where $n$ is the number of words that separate the terms from the two columns; and column A was combined with the combination of $\mathrm{B}$ and $\mathrm{C}$ using the AND command. vi

Table 1. Key terms for search strategy

\begin{tabular}{|l|l|l|}
\hline A & B & C \\
Policy & Income & Inequality \\
\hline Polic* & Income* & *Equal* \\
Intervention* & Expenditure* & *Distribut* \\
Program* & & Disparit* \\
Instrument* & & Differen* \\
Tool* & & Gap* \\
Reform* & *Equit* \\
Legislation* & Share* \\
Govern* & & Ratio* \\
& & Gini \\
\hline
\end{tabular}

Notes: * is included as a truncation symbol to capture automatically conjugated forms of each word; thus *equal* captures "inequality" as well as "inequalities"; *distribut* captures "distribution" as well as "redistribution".

In addition to these electronic searches, we carried out some additional searches using handsearching.

\section{Inclusion Criteria}

Our inclusion criteria follow standard procedures commonly used in the systematic review context. In terms of types of participants (population), the review is restricted to studies of low income 
countries (LICS) and middle income countries (MICS) at the time of the government intervention; studies which focus only on high income countries are excluded. The World Bank definitions of LICS and MICs are used in applying this criterion. Note however that many studies include countries from all income groups (low, middle and high) in the analysis; we include such studies, on the grounds that they typically contain a significant proportion of low and middle income countries. However, we exclude studies which focus predominantly on high income countries.

The vast majority of studies involve comparisons of inequality across countries and over time, using panel data, although there are also some single-county studies using time series analysis. The analysis is restricted to studies focusing on income inequality at the national level. We include studies that focus on inequality in a comprehensive measure of income that includes income from all sources (e.g. wages and salaries, business profits, investment earnings, rental income, transfers). We include studies that focus on inequality in market (pre-fiscal) income, disposable (post-fiscal) income, or total consumption expenditure; the latter is often considered to be a more reliable indicator when data on income are difficult to collect. We require that data on income or expenditure be drawn from a representative household survey covering all of the relevant population. Inequality may be measured using either a global or partial measure of inequality (e.g. the Gini coefficient, or the share of the poorest quintile in national income), measured across households or individuals.

We include studies that use econometric analysis to estimate the effects of government spending on income inequality. They involve estimating a regression in which a measure of income inequality is the dependent variable and the explanatory variables include a measure of government spending; examples include government spending on health, education, or social welfare, as a share of GDP. This can be written in general terms as:

$$
I_{i t}=\beta_{0}+\beta_{1} X_{i t}+\beta_{k} Z_{i t k}+\varepsilon_{i t}
$$

where $I$ is a valid measure of income inequality, $X$ is a measure of government spending, $Z$ is a vector of other explanatory variables, and $\varepsilon$ is the error term, with subscripts $i$ and $t$ indicating country and year respectively. Note that one exception occurs in the case of an approach first used by Dollar and Kraay (2002), and adopted since then by other researchers (e.g. Dollar et al 2013). This involves a regression of the average income of the poorest quintile(s) on the average per capita income of the population as a whole, as well as a measure of government spending and other explanatory variables. Although the dependent variable in this case is not a valid measure of inequality, the coefficients obtained from this type of regression are identical to those obtained from equation (1) when the dependent variable is the share of the poorest quintile(s) in national income, which is a valid measure of inequality. Studies using this type of approach are therefore included in the review.

Finally, we include published and unpublished studies, including refereed and non-refereed journal articles, working papers, conference proceedings, book chapters, government reports, NGO reports and other technical reports. We restrict the review to studies published since 1990. This is mainly on the grounds that reliable, cross-country data on income inequality have only been available since the 
early 1990s, so that any studies before this date would not meet basic requirements in terms of data quality. Our review is also restricted to studies published in English, Portuguese, and Spanish.

\section{Meta-regression approach}

We carry out a meta-regression analysis for government spending variables and their effect on inequality and follow the MAER-NET guidelines to report our findings (see Stanley et al, 2013:393). Our approach also follows Abdullah et al (2015) who examined the impact of education on income inequality using a meta-regression approach. Before presenting the meta-regression findings however, we first discuss our effect size measure, our initial tests for publication bias, and our overall modelling approach.

\section{Effect sizes}

All regression-based estimates were converted into a comparable measure, the partial correlation coefficient which was the best choice given our particular context. The partial correlation measures the strength of association between income inequality and government spending, holding all other factors constant. It is calculated as follows:

$$
r=\frac{t}{\sqrt{t^{2}+d f}}
$$

where $t$ is the t-statistic of the regression coefficient and $\mathrm{df}$ is the degrees of freedom from the $\mathrm{t}$ statistic (Stanley and Doucouliagos, 2012). vii If the t-statistic was not reported we calculated it by dividing the regression coefficient by its standard error. We had a few studies that did not report the $t$-statistic or the standard error but we had the exact $p$-value and the degrees of freedom. In these cases we used the TINV function in Excel which allowed us to calculate the t-statistic using the pvalues as well as the degrees of freedom (see Stanley and Doucouliagos, 2012, footnote 45). In some cases we did not even have the exact $p$-value and only the levels of statistical significance were given such as * (for 10\%), ** (for 5\%) and *** (for 1\%). Stanley and Doucouliagos (2012) argue that in such cases the analyst will have to decide whether or not the estimates should be included. We decided to include them and followed the simplest approach Stanley and Doucouliagos (2012:31) suggested, namely to assume that the $\mathrm{p}$-value is 0.01 if the significance level is given as $* * *, 0.05$ if the significance level is given as $* *$ and so on. We then used these p-values as well as the degrees of freedom to calculate the t-statistic using the TINV function in Excel again. We excluded any study that did not report any of the above statistics and therefore did not enable us to calculate the partial correlation coefficient.

We should note that a number of effect size measures exist in the meta-analytical context such as standardised mean differences, odds and risk ratios as well as partial correlation coefficients. We narrowed down the list of possible effect size calculations closely looking at the data reported in the studies we included in our meta-regression approach. The vast majority of the included studies reported regression coefficients, t-statistics and standard errors. Hence, we chose the partial correlation coefficient as it can be calculated easily from regression output requiring only limited information. It is a unitless measure allowing comparisons within and between studies as well as 
comparisons involving variables using different scales such as Gini coefficients and income shares (Stanley and Doucouliagos, 2012; Abdullah et al, 2015). It is often argued that the partial correlation coefficient should be converted into Fisher's $z$ scale as the partial correlation coefficient is truncated at -1 and +1 which can cause problems. These problems can be overcome by running the metaregression on the Fisher's z transformations, though Hunter and Schmidt (2004) cast doubts about using this transformation. Despite these doubts we used the command corrci in STATA to transform our partial correlation coefficients to Fisher's z scale but this made little difference to our results which is not surprising if one follows the arguments set out by Stanley and Doucouliagos (2012) and Abdullah et al (2015).

We were able to extract 952 estimates of the partial correlation coefficient, from 84 studies. Of these, 331 recorded positive partial correlations between a government spending variable and income inequality, with 86 of these being statistically significant at the $10 \%$ level or below. 621 of the estimates recorded negative partial correlations with 277 of these being statistically significant (see Online Appendix Table A2.1 for details). viii

\section{Publication bias}

Publication bias is a serious issue in particular in the context of systematic reviews as it can introduce serious biases in the meta-analytical results. It is argued that studies reporting statistically significant findings are more likely to be published in peer-reviewed journals than studies reporting statistically insignificant findings. This bias in the literature will then also be reflected in the meta-analysis as published studies are more likely to be included in a meta-analysis (Borenstein et al 2009).

The funnel plot is one of the most common methods to illustrate the presence of publication bias (see for example Egger et al 1997). Figure 1 illustrates a funnel plot which plots the effect size on the $x$-axis, here the partial correlation coefficient between measures of government spending and income inequality, and precision (or the inverse of the standard error of the partial correlation coefficient) on the $y$ axis. At the bottom of the graph we find the estimates with less precision, i.e. with the larger standard errors, while the estimates with more precision, i.e. smaller standard errors, are more towards the top of the funnel plot. Visual inspection suggests that there is no publication bias present when the studies are distributed symmetrically. In this case a first inspection of the funnel plot suggests symmetry as both positive and negative estimates are evenly distributed around the mean value of the partial correlation coefficient $(-0.083)$, indicated by the solid vertical line. 
Figure 1. Funnel Plot, Partial Correlations of Government Spending and Income Inequality ( $n=952)$

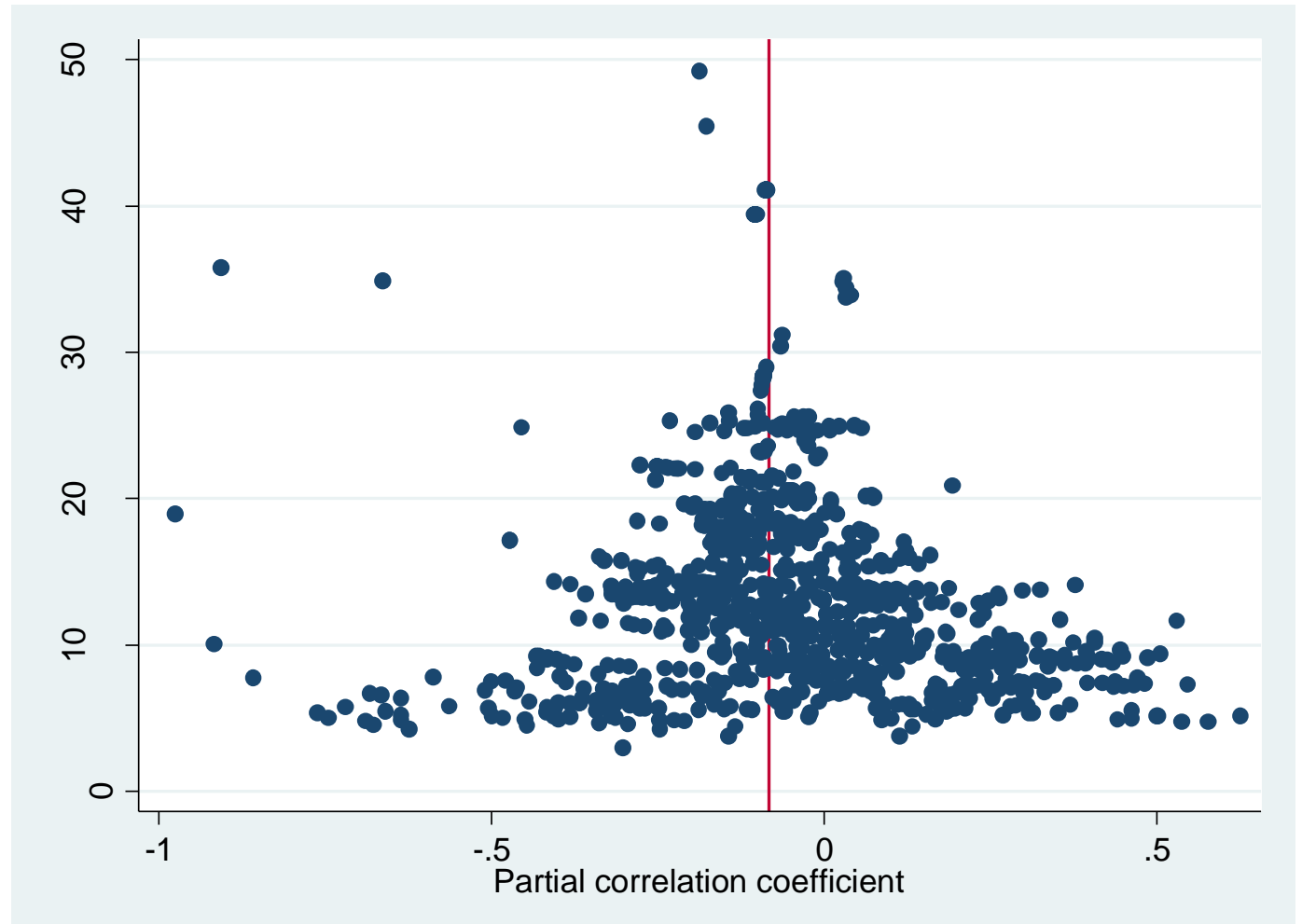

Note: Precision is calculated as 1 /standard error of the partial correlation coefficient. The weighted mean of the partial correlation coefficient is marked with a red line with the value of -0.083 (s.e. $=0.005$ ).

However, visual inspections of publication bias can be subjective (Borenstein et al, 2009; Abdullah et al, 2015) and thus Stanley $(2005,2008)$ suggests the use of the FAT-PET (Funnel-Asymmetry Precision-Effect) regression as an empirical test to check more reliably for any publication bias. We carry out this test as part of our meta-regression analysis.

Note that a visual inspection of Figure 1 indicates the presence of a few outliers, particularly in the upper left corner. These estimates were double checked to ensure they had been correctly entered and coded. We proceed with presenting the meta-regression results removing the outliers as an in depth inspection of the nine outliers from four studies indicated potential errors in the effect sizes reported in the respective studies; for example, reported t-statistics were abnormally high. 


\section{Modelling heterogeneity}

Although our inclusion criteria are designed to identify a set of broadly similar studies, we suspect that a certain degree of heterogeneity remains. This view is confirmed by the funnel plot we presented in Figure 1, as the reported estimates are rather spread out. To better understand what drives this heterogeneity we follow Abdullah et al (2015) and adopt the following meta-regression model to explore heterogeneity in the reported estimates:

$$
r_{i j}=\beta_{1}+\sum \beta_{k} Z_{k i}+\beta_{0} S E_{i j}+\varepsilon_{i j}
$$

where $r$ is the partial correlation coefficient expressing the link between a measure of government spending and a measure of income inequality, of the ith estimate from the $j$ th study. $\mathbf{Z}$ is a vector of variables that capture differences in the relationship between government spending and income inequality. $S E$ is the standard error of the partial correlation coefficient and $\varepsilon_{i j}$ is the error term. The standard error of the partial correlation coefficient is calculated as follows: ${ }^{\text {ix }}$

$$
S E=\frac{r}{t}
$$

The following variables are included in the $\mathbf{Z}$ vector (see Table 2 ):

Measures of the dependent variable: Our variable of interest is income inequality. We included any study that used a recognized measure of income inequality. While most studies use the Gini coefficient, a substantial proportion use measures based on income shares (e.g. the share of the poorest $10 \%$ or $20 \%$ of households in national income, or the ratio of the income share of the richest $20 \%$ of households to that of the poorest $20 \%$ ).

Measures of government spending: Government spending was coded into 10 different categories: total, health, education, health \& education, social welfare, military, housing, social (general), consumption and others (see Table 2). ${ }^{x}$ Our meta-regression model aims to test the differential impact of these different types of government spending measures on the reported results.

Country composition: The main geographical areas covered include Sub-Saharan Africa, Latin America, South Asia, East Asia \& Pacific, Middle East \& North Africa and Eastern Europe \& Central Asia. Although our main focus is on low and middle income countries, over half of the estimates are based on samples including data from high income countries.

Data: Most estimates are based on a non-OLS method, e.g. dynamic panel estimators such as generalised method of moments (GMM), more traditional panel data analysis using random and/or fixed effects, or other econometric approaches such as instrumental variables, 2 or 3-stage least squares, propensity score matching, differences-in-differences or similar. The average year of the data used was included to account for different time periods and spans, as the relationship between government spending and income inequality may vary over time. The variable was transformed as follows: Yr= Year data- average year data (1986). 
Other explanatory variables: Most studies include a range of explanatory variables in their regressions. In our MRA we include variables corresponding to whether any of the following six control variables were included: trade policy, tax revenue, inflation, governance, education and population. The variables are coded 1 if they are included in the regressions as explanatory variables and 0 if otherwise. These specific variables were chosen after careful reviewing all included studies and counting the variables that appear more frequently. Three correspond to different ways of financing government spending: tax revenue, trade policy, and inflation. The tax revenue category includes measures of total, direct and indirect tax revenue, typically measured as a share of GDP. The trade policy category incorporates a range of measures of trade policy, including import tariffs, export duties, non-tariff barriers and trade policy indices. Inflation includes any measure of changes in the price level. The governance category was included to reflect the potential influence of democracy and institutional factors on the effectiveness of government spending, as proxied by voice and accountability, corruption, and so on. Education variables include years of education and schooling-related variables like educational attainment, enrolment rates or human capital. Population appeared frequently in the specifications and it was decided to include this variable as well.

Publication: The standard error of the partial correlation coefficient is included to account for publication bias. We also account for differences between published and unpublished studies. ${ }^{\mathrm{x}}$

More detailed descriptive information for each variable, including their mean values and standard deviations, is reported in the Online Appendix in Table A2.2. We should note that we decided to run our meta-regression analysis with and without outliers. The results without the outliers are presented in the main text for reasons explained above, while the findings with outliers are presented in the Online Appendix in Table A3.1. We prefer the findings without outliers as we suspect errors in the reported effect sizes among the estimates we visually identified as outliers. We typically only observe small differences between the regressions with and without outliers; we comment further below on the few cases in which they do differ. We also acknowledge that there are meta-analyses that employ Bayesian model averaging techniques (see for example Moeltner and Rosenberger, 2008; Iršová and Havránek, 2013). Although this approach has not been adopted in the paper, it can be used to deal with model uncertainties and identify the most appropriate set of explanatory variables given a particular study context.

Estimations are carried out using a regression procedure with a weighted least squares (WLS) routine that Stanley and Doucouliagos (2013 and forthcoming, 2016) advocate in a recent set of papers. They demonstrate how an unrestricted WLS-MRA is likely to be as good as and often better than both random-effects and fixed-effect meta-analysis and meta-regression analysis in practical applications (using the command metareg in STATA). The majority of the studies we included reported more than one result that could be used to calculate the partial correlation coefficient, none of the studies specified a preferred result, and thus we were faced with multiple dependent estimates per study. This needs to be dealt with appropriately to avoid bias due to data dependency (Lipsey and Wilson, 2001: 105, 125). The literature suggests a number of approaches to dealing with multiples estimates per study (see for example Lipsey and Wilson, 2001; Borenstein et al, 2009:230) and there is no consensus on the preferred approach. Thus, in the Online Appendix in Table A4.1, we explore different approaches to dealing with multiple dependent estimates per study as robustness checks. Following Abdullah et al (2015), our preferred approach to accounting for multiple estimates 
per study is to use precision squared (inverse variance or $1 /$ standard error squared) as weights with study level clustered standard errors.

Finally, the data used for the meta-regression analysis as well as the corresponding STATA do files are available from the authors on request.

Table 2. Meta-regression variable definitions

\begin{tabular}{|c|c|}
\hline Variable name & Variable description \\
\hline \multicolumn{2}{|l|}{ Inequality measure } \\
\hline Gini & $\mathrm{BD}=1$ : Gini coefficient (used as the base) \\
\hline Income Share Bottom & $\mathrm{BD}=1$ : Income share of the bottom decile or quintile(s) \\
\hline Income Share Top & $\mathrm{BD}=1$ : Income share of the top decile or quintile(s) \\
\hline Income Share Ratio & $\mathrm{BD}=1$ : Income share ratios \\
\hline Theil index & $\mathrm{BD}=1:$ Theil index \\
\hline \multicolumn{2}{|l|}{ Government spending measure } \\
\hline Total spending & $\mathrm{BD}=1$ : Total government spending (used as the base) \\
\hline Health spending & $\mathrm{BD}=1$ : Health government spending \\
\hline Education spending & $\mathrm{BD}=1$ : Education government spending \\
\hline Health \& Education spending & $\mathrm{BD}=1$ : Health \& Education government spending \\
\hline Social welfare spending & $\mathrm{BD}=1$ : Social welfare spending \\
\hline Military spending & $\mathrm{BD}=1$ : Military government spending \\
\hline Housing spending & $\mathrm{BD}=1$ : Housing government spending \\
\hline Social spending (general) & $\mathrm{BD}=1$ : Social government spending (general) \\
\hline Consumption spending & $\mathrm{BD}=1:$ Government spending (consumption) \\
\hline Other spending & $\mathrm{BD}=1$ : Government spending (any/not specified/other) \\
\hline \multicolumn{2}{|l|}{ Country composition } \\
\hline Sub-Saharan Africa (SSA) & $\mathrm{BD}=1$ : Countries in Sub-Saharan Africa included in samples \\
\hline Latin America (LAC) & $\mathrm{BD}=1$ : Countries in Latin America included in samples \\
\hline South Asia (SA) & $\mathrm{BD}=1$ : Countries in South Asia included in samples \\
\hline East Asia \& Pacific (EAP) & $\mathrm{BD}=1$ : Countries in East Asia \& Pacific included in samples \\
\hline Middle East \& North Africa (MENA) & $\begin{array}{l}\mathrm{BD}=1 \text { : Countries in Middle East \& North Africa included in } \\
\text { samples }\end{array}$ \\
\hline $\begin{array}{l}\text { Eastern Europe \& Central Asia } \\
\text { (EECA) }\end{array}$ & $\begin{array}{l}\mathrm{BD}=1 \text { : Countries in Eastern Europe \& Central Asia included in } \\
\text { samples }\end{array}$ \\
\hline Developed & $\mathrm{BD}=1$ : Developed countries included in samples \\
\hline \multicolumn{2}{|l|}{ Data } \\
\hline OLS & $\mathrm{BD}=1:$ OLS estimator used \\
\hline Year data & $\begin{array}{l}\text { Average year of data used in each study minus average year } \\
\text { data of the sample }\end{array}$ \\
\hline \multicolumn{2}{|l|}{ Other explanatory variables } \\
\hline Tax & $\mathrm{BD}=1:$ Tax revenue included as explanatory variable \\
\hline Trade & $\mathrm{BD}=1$ : Trade policy measure included as explanatory variable \\
\hline Education & $\mathrm{BD}=1$ : Education variable included as explanatory variable \\
\hline Inflation & $\mathrm{BD}=1$ : Inflation included as explanatory variable \\
\hline Population & $\mathrm{BD}=1$ : Population included as explanatory variable \\
\hline Governance & $\mathrm{BD}=1:$ Governance variable included as explanatory variable \\
\hline \multicolumn{2}{|l|}{ Publication } \\
\hline Standard error & Standard error of the partial correlation coefficient \\
\hline Unpublished & $\mathrm{BD}=1$ : Study is unpublished \\
\hline
\end{tabular}


Notes: * BD means binary dummy with a value of 1 if condition if fulfilled and zero otherwise.

\section{Main meta-regression findings}

We present the main findings of our meta-regression analysis in Table 3, where we seek to establish whether there is a relationship between government spending and income inequality, and what explains the heterogeneity in this relationship. Regression 1 reports the FAT-PET results where the standard error of the partial correlation coefficient is regressed on the partial correlation coefficient. Recall that the FAT-PET regression is an empirical check to explore publication bias. The results indicate that there is some publication bias as the coefficient for the standard error is statistically significant. The amount of publication bias implied by regression 1 is not that large: the average relationship between government spending and income inequality, after correcting for publication bias, is -0.111 (s.e.= 0.021), which is not substantially different from the average relationship when not correcting for publication bias $(-0.083$, s.e. $=0.005)$. In addition, the coefficient on the standard error term is statistically significant only at the $10 \%$ level. We have also run the FAT-PET model with study fixed effects (see Online Appendix Table A5.1.). These results broadly confirm the results of the basic model in Table 3, although the coefficient is no longer statistically significant when including fixed effects and using cluster-robust standard errors. The coefficient for the standard error is positive, indicating that the estimated partial correlation coefficients are skewed towards positive values; negative effects are being under-reported in the literature. The constant in regression 1 quantifies the overall or average relationship between government spending and income inequality, after correcting for publication bias. This takes the value of -0.111 , which is statistically significant at a $1 \%$ significance level, implying a statistically significant negative relationship between government spending and income inequality.

In regression 2 additional dummy variables are added representing different income inequality measures, to explore whether the relationship differs depending on the income inequality measure that has been adopted. The values for income share bottom, income share ratio and Theil index are positive and statistically significant at $5 \%, 10 \%$ and $1 \%$ in that order. ${ }^{\text {xi }} \mathrm{A}$ positive effect for a moderator variable means that the variable results in a larger positive (or smaller negative) relationship between government spending and income inequality. Only the value for income share top has a negative and statistically significant effect at 10\%. The results in Regression 2 indicate that in the case of using the Gini coefficient there is an average relationship of -0.108 (significant at $1 \%$ ) between government spending and income inequality, after correcting for publication bias. On the other hand, the relationship is slightly positive when income share ratio $(0.057)$ and Theil index (0.233) are used. This, however, is not the case for income share bottom (-0.047 - the estimate is not statistically significant). ${ }^{\text {iii }}$

Regression 3 is our main model as it includes all potentially relevant explanatory variables described above. Of the moderator variables for the control variables (tax, trade, governance, inflation, education and population), governance is positive and statistically significant at the $10 \%$ level. This implies that studies which control for governance indicators report a smaller negative (or larger positive) relationship between government spending and income inequality, other things being equal. The same logic applies to the trade variable which is positive and statistically significant at the $1 \%$ level implying that studies controlling for trade policy indicators report smaller negative relationships between government spending and income inequality. By contrast, the coefficient for 
inflation is negative and statistically significant (at the $1 \%$ level), indicating that studies that control for inflation report a larger negative (or smaller positive) relationship between government spending and income inequality. In terms of the variables for sample coverage, the picture is similar as the variable for LAC is negative and significant at the $1 \%$ level, indicating that studies including Latin American countries in the sample find a larger negative (or smaller positive) relationship. None of the other moderator variables for control variables or sample coverage are statistically significant however.

We are particularly interested in the results for the disaggregated measures of government spending. We find a positive and statistically significant effect (at 10\%) for military spending. Similarly, the coefficient for health and education spending is also positive and statistically significant at the $1 \%$ level. This indicates that studies focusing on health and education spending find on average a larger positive (or smaller negative) relationship between spending and inequality than studies using total spending. This is perhaps surprising, since health and education are often considered to be relatively 'pro-poor' components of government spending (Mosley et al. 2004), although there is evidence from studies such as Tanzi (1974), Alesina (1998) and Davoodi et al (2003) suggesting that much of the benefits of government spending on health and education in developing countries are received by middle-income groups in urban areas, which can end up raising inequality. Note however that we have only five observations for this particular measure of spending. In addition, we do find a negative and statistically significant effect (at the $5 \%$ level) for social spending (general), which includes social welfare spending as well as health and education spending.

We are also particularly interested in the results for the OLS variable, which captures the different analytical approaches used. The coefficient for this variable is negative and statistically significant at the $5 \%$ level. This implies that studies using OLS as an estimation method report, on average, larger negative (or smaller positive) correlations between government spending and income inequality, holding all other MRA variables constant.

In regression 4 we follow Leonard, Stanley and Doucouliagos (2014) and employ a general-to-specific modelling strategy, removing the variable that has the largest $p$-value until all $p$-values are $<0.05$. The rationale for employing a general-to-specific approach can be found in Stanley and Doucouliagos (2012) who argue that they prefer a more specific model as it makes the underlying associations clearer. In the specific model (regression 4) we observe that income share bottom, Theil index, trade, health and education spending and military spending are statistically significant and positive (except other spending which was not significant in regression 3 ) as already seen in regression 3 . In addition income share top, $L A C$ and inflation are negative and statistically significant, at $5 \%$ for income share top and $1 \%$ for $L A C$ and inflation as already observed in regression 3 as well.

Finally in regression 5 we report the estimates from a robust regression which strengthen our findings further. ${ }^{\text {xiv }}$ We should note that of the 12 variables that are statistically significant at the $10 \%$ level or below in regression 3, 11 remain significant in regression 5; these are standard error, income share bottom, income share top, Theil index, OLS, LAC, governance, inflation, health and education spending, military spending and social spending (general). In addition, when we compare the results in Table 3 with those in the Online Appendix in Table A3.1. (which includes outliers), we typically only observe very small differences. Of the 11 coefficients which are statistically significant in regressions (3) and (5) in Table 3, seven retain the same sign and remain statistically significant when 
including outliers. These are standard error, income share bottom, Theil index, OLS, inflation, health \& education spending, and social spending (general) (see Appendix 3, Table A3.1.). In addition, six of the 11 coefficients retain the same sign and remain statistically significant in at least four out of the five different weighting schemes that we consider (see Appendix 4, Table A4.1.), as do 6 out of 8 when restricting the analysis to observations using the Gini coefficient (see Appendix 6, Table A6.1.; the three variables for inequality measures drop out of the model in this case). These are income share top, Theil index, inflation, health \& education spending, military spending, and social spending (general) (Table A4.1.) and LAC, governance, inflation, health \& education spending, military spending, and social spending (general) (Table A6.1.).

The only case in which we observe more substantial differences with the results in Table 3 is when we include study-level fixed effects. In this case, only 4 of the 11 coefficients retain the same sign and remain statistically significant at the $10 \%$ level or below; these are income share bottom, Theil index, military spending, and social spending (general) (see Table A7.1.). In addition, in contrast to Table 3, the coefficients for the regional variables are larger in size and all statistically significant, and the coefficient for $L A C$ is now positive rather than negative. We are uncertain as to what may be driving these differences with the results in Table 3. As noted above, there is no consensus on the ideal approach in meta-regression analysis for dealing with multiple estimates per study. Our main approach, following other recent research (e.g. Abdullah et al 2015), has been to use WLS with a range of different possible weighting schemes, combined with cluster-robust standard errors. It is clear however that the use of study-level fixed effects leads to somewhat different results, which casts doubt on the robustness of some (but not all) of the results in Table 3. We believe that this is an area for further research. 
Table 3. MRA of the effects of government spending on income inequality

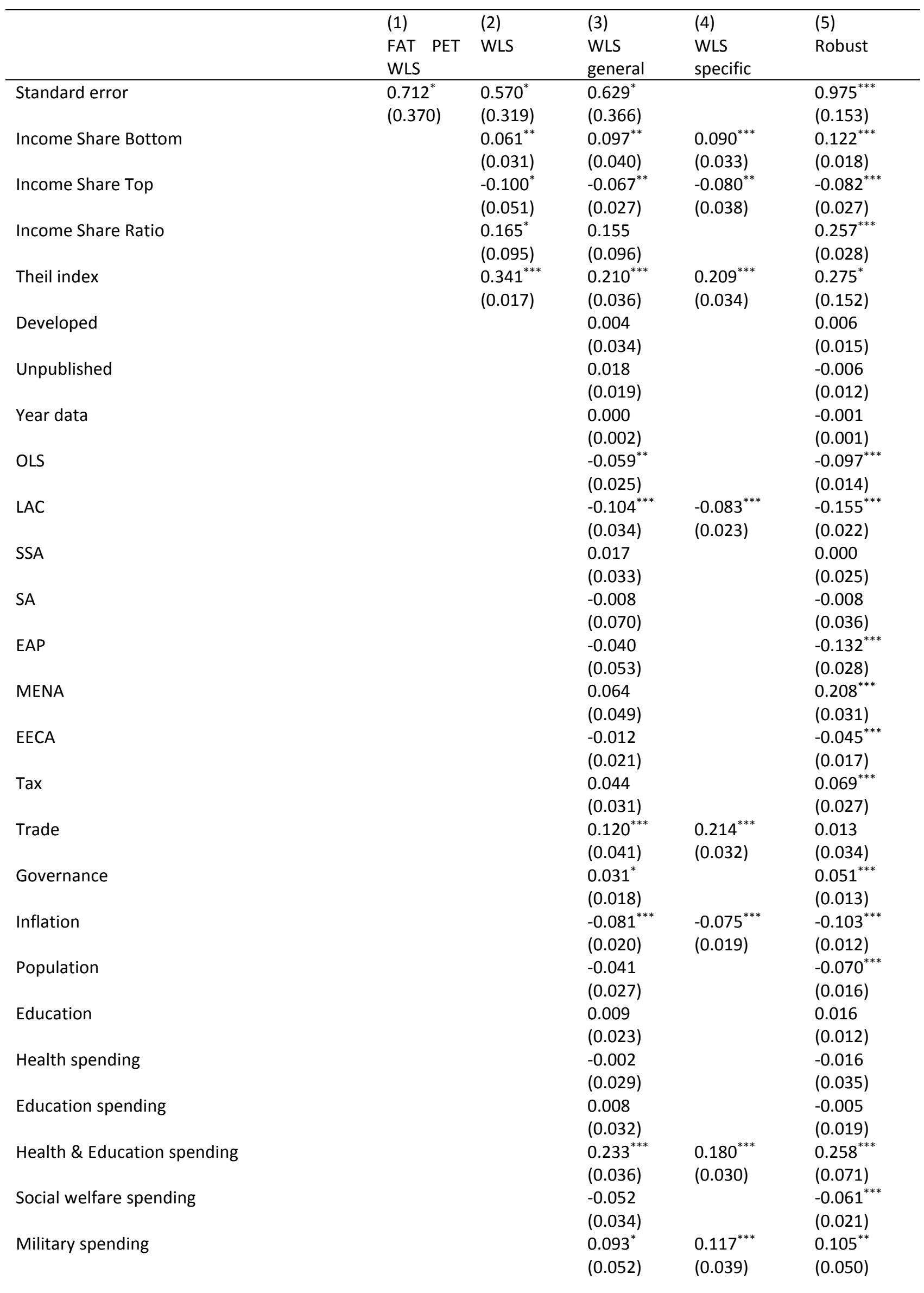




\begin{tabular}{|c|c|c|c|c|c|}
\hline Housing spending & & & $\begin{array}{l}0.013 \\
(0.029)\end{array}$ & & $\begin{array}{l}0.024 \\
(0.065)\end{array}$ \\
\hline \multirow[t]{2}{*}{ Social spending (general) } & & & $-0.095^{* *}$ & & $-0.078^{*}$ \\
\hline & & & $(0.044)$ & & $(0.046)$ \\
\hline \multirow[t]{2}{*}{ Consumption spending } & & & -0.019 & & $-0.037^{* *}$ \\
\hline & & & $(0.025)$ & & $(0.016)$ \\
\hline \multirow[t]{2}{*}{ Other spending } & & & 0.036 & $0.089^{* * *}$ & 0.037 \\
\hline & & & $(0.032)$ & $(0.020)$ & $(0.039)$ \\
\hline \multirow[t]{2}{*}{ Constant } & $-0.111^{* * *}$ & $-0.108^{* * *}$ & -0.013 & 0.024 & 0.033 \\
\hline & $(0.021)$ & $(0.019)$ & $(0.049)$ & $(0.024)$ & $(0.028)$ \\
\hline$N$ & 943 & 943 & 943 & 943 & 943 \\
\hline$R^{2}$ & 0.027 & 0.095 & 0.274 & 0.177 & 0.458 \\
\hline
\end{tabular}

Notes: The dependent variable in all regressions is the partial correlation coefficient. Standard errors are reported in parentheses. All regressions use cluster standard errors to adjust for data dependence, i.e. multiple estimates per study. Outliers have been removed for all regressions. All columns use weighted least squares using inverse variance weights, except for regression 5 that uses robust regression. In regression 4 we employed a general-to-specific modelling strategy, removing the variable that had the largest $p$-value until all $p$-values are $<0.05$. For definitions of variables see Table 2 . Total government spending is used as the base category for the government spending variable. GINI is used as a base in the inequality variable. In order to test for multicollinearity we use the Variance Inflation Factor (VIF) for both the general (3) and specific regressions (4); the mean VIF is 3.65 and 1.06, respectively, which is not a cause for concern. According to Hosmer and Lemeshow (2000) values of VIF exceeding 10 are often regarded as indicating multicollinearity and should be investigated. Regression (5) is a robust regression which is unweighted. As a robustness check we rerun the results in Table 3 using only the Gini coefficient as the measure of income inequality. The results are presented in the Online Appendix in Table 6.1.

${ }^{*} p<0.1,{ }^{* *} p<0.05,{ }^{* * *} p<0.01$

\section{Robustness checks - what do subgroup analyses tell us?}

To check further the robustness of our findings we conduct a range of subgroup analyses. In Table 4 we explore how our findings differ by the different categories of government spending, focusing on the four measures of government spending where we had sufficient number of observations. For the remaining government spending variables most of the variables of interest were omitted due to the low number of observations and hence we felt there is not much value in presenting them here. Regression 1 shows the results for total spending, Regression 2 the results for education spending, Regression 3 the results for social welfare spending, and Regression 4 the results for consumption spending, respectively.

The findings in Table 4 show some interesting differences between the results for different spending measures. In regressions 1 and 4 for example, the coefficients for income share bottom are both positive and statistically significant at $1 \%$. This indicates that, compared to studies that use the Gini coefficient, studies that use these measures find a smaller negative (or larger positive) relationship between total spending as well as consumption spending and inequality, ceteris paribus.

The results for the average year of the data used also differ somewhat between spending measures. This variable is included in order to explore whether the relationship between government spending and inequality varies with time. The coefficient is positive and statistically significant in regressions 1 , i.e., when total spending is used. This suggests that, holding all else constant, studies that use more recent data find a smaller negative (or larger positive) relationship between total spending and income inequality in comparison with studies using older data. This finding is the opposite for 
regression 3, i.e. when social welfare spending is used, where the coefficient for average year of the data is negative and statistically significant at $1 \%$.

Particularly interesting are the results for the regional variables. For example, consider the results for Latin America (LAC). The negative coefficient for this variable in regression 1 (statistically significant at the 10\%) suggests that studies including Latin American countries in the sample find a larger negative (or smaller positive) relationship between total spending and income inequality. By contrast, the positive coefficients for Sub-Saharan Africa (SSA) and East Asia \& Pacific (EAP) in the same regression indicate that studies including countries from these regions find a less negative (or larger positive) relationship between total spending and income inequality. One possible explanation for these results is that government spending has a greater effect in reducing income inequality in Latin America than in Sub-Saharan Africa or East Asia \& Pacific. Note however that the results for social welfare spending and consumption spending in regression 3 and 4 show larger negative (smaller positive) relationship with income inequality for studies including countries from SubSaharan Africa. The same applies to countries from the East Asia \& Pacific region in regression 4.

As in Table 3, the sub-group analysis in Table 4 suggests that the inclusion of different control variables in econometric models influences the partial correlation between government spending and income inequality. Studies that control for trade find a smaller negative (or larger positive) relationship between total spending and inequality. The education variable is statistically significant in regression 2, implying that the inclusion of this control variable in studies of the relationship between education government spending and income inequality is particularly appropriate.

The results in Table 4 also suggest differences in publication bias across the different spending measures. For estimates based on total spending: the coefficient on the standard error is positive and statistically significant. For education spending and consumption spending by contrast, the coefficient on the standard error is not statistically significant. In addition, for social welfare spending, the coefficient on the standard error is negative and statistically significant. For this measure of spending therefore, we conclude that positive estimates of the relationship between spending and inequality are being under-reported in the literature.

In Table 5 we conduct a series of other subgroup analyses with the objective to explore additional aspects in the data and to check the robustness of our main findings (note also that the Online Appendix in Table A4.1. presents further robustness checks). We were particularly interested to explore how our findings might differ by region (Latin America, Sub-Saharan Africa, East Asia \& Pacific and Middle East and North Africa) and check whether the inclusion of developed countries in the sample makes a difference.

The results from Table 5 strengthen our previous discussion and results. In regressions 3-8 (i.e. studies including developed/developing countries, Latin American, Sub-Saharan African, East Asia Pacific and Middle East and North African countries in the sample) two measures of government spending are consistently positive and statistically significant (health \& education and military) indicating that these categories of government spending report smaller negative (or larger positive) partial correlations with income inequality. By contrast, in regressions 3 and regressions 5-8 (studies including the Latin American, Sub-Saharan African, East Asian and Middle East \& North African regions in the sample) social welfare spending has a negative and statistically significant value, meaning that the relationship with inequality is on average more negative (less positive) for this 
measure of spending. Social spending (general) is also negative and statistically significant at the $5 \%$ level in samples that include Latin American countries. These results are consistent with the hypothesis that the relationship between government spending and income inequality varies significantly across regions. 
Table 4. Subgroup analysis for government spending variables

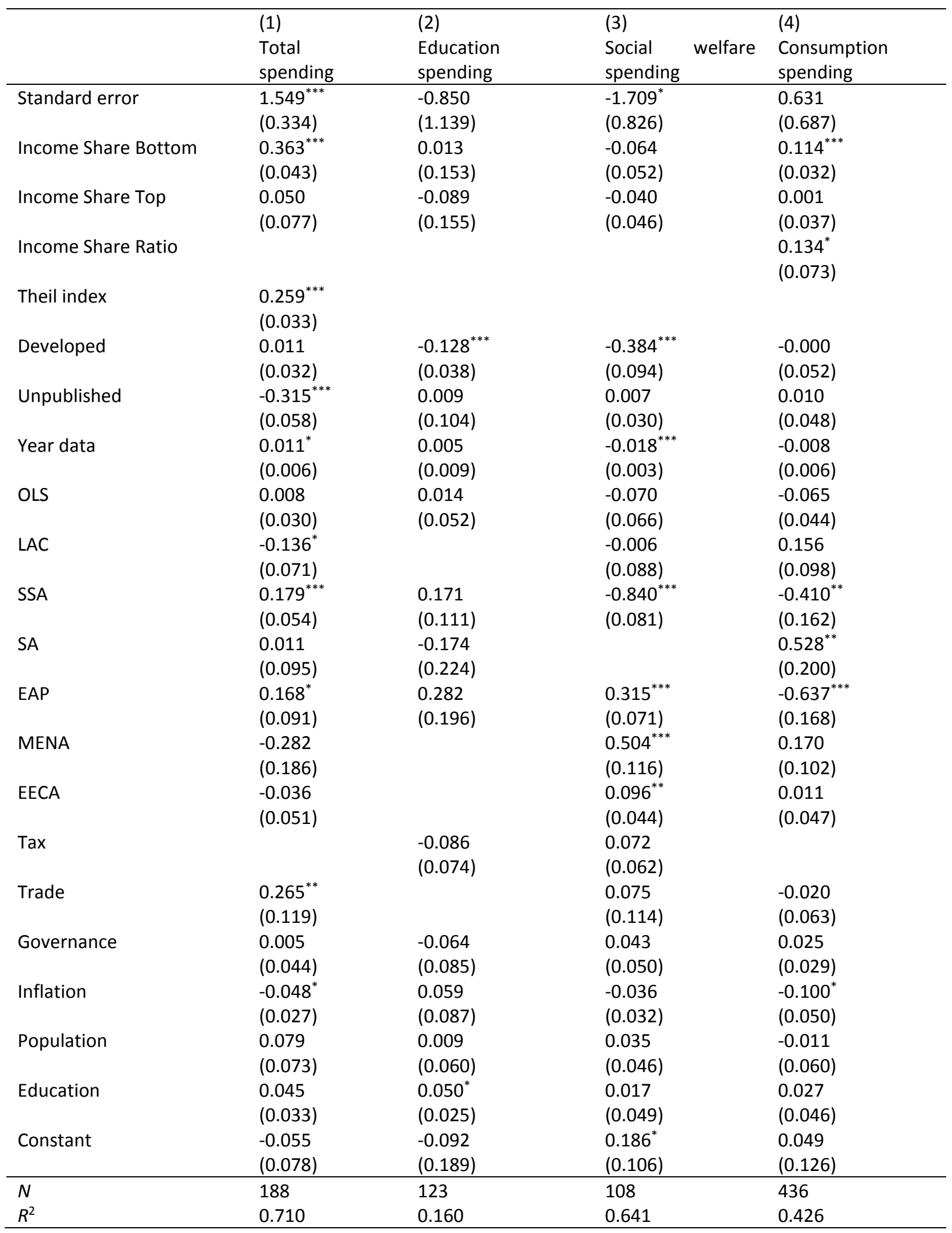

Notes: The dependent variable in all regressions is the partial correlation coefficient. Standard errors are reported in parentheses. All regressions use cluster standard errors to adjust for data dependence, i.e. multiple estimates per study. Outliers have been removed for all regressions. All columns use weighted least squares using inverse variance weights.

${ }^{*} p<0.1,{ }^{* *} p<0.05,{ }^{* * *} p<0.01$. 
Table 5. Subgroup analysis for selected non-government variables

\begin{tabular}{|c|c|c|c|c|c|c|c|c|}
\hline & $\begin{array}{l}(1) \\
\text { FAT PET } \\
\text { WLS }\end{array}$ & $\begin{array}{l}(2) \\
\text { WLS } \\
\text { general }\end{array}$ & $\begin{array}{l}\text { (3) } \\
\text { Develope } \\
d, \text { yes=1 }\end{array}$ & $\begin{array}{l}\text { (4) } \\
\text { Develope } \\
d, \\
\text { no=0 }\end{array}$ & $\begin{array}{l}(5) \\
\text { Latin } \\
\text { America, } \\
\text { yes=1 }\end{array}$ & $\begin{array}{l}\text { (6) } \\
\text { Sub- } \\
\text { Saharan } \\
\text { Africa, } \\
\text { yes=1 }\end{array}$ & $\begin{array}{l}\text { (7) } \\
\text { East Asia } \\
\text { Pacific, } \\
\text { yes=1 }\end{array}$ & $\begin{array}{l}(8) \\
\text { Middle } \\
\text { East } \\
\text { North } \\
\text { Africa, } \\
\text { yes=1 }\end{array}$ \\
\hline $\begin{array}{l}\text { Standard } \\
\text { error } \\
\text { Income Share } \\
\text { Bottom }\end{array}$ & $\begin{array}{l}0.712^{*} \\
(0.370)\end{array}$ & $\begin{array}{l}0.629^{*} \\
(0.366) \\
0.097^{* *} \\
(0.040)\end{array}$ & $\begin{array}{l}1.125^{* * *} \\
(0.347) \\
0.155^{* * *} \\
(0.044)\end{array}$ & $\begin{array}{l}-0.403 \\
(0.894) \\
-0.002 \\
(0.054)\end{array}$ & $\begin{array}{l}1.129^{* * *} \\
(0.327) \\
0.106^{* *} \\
(0.041)\end{array}$ & $\begin{array}{l}1.105^{* * *} \\
(0.376) \\
0.079^{* *} \\
(0.036)\end{array}$ & $\begin{array}{l}0.774^{*} \\
(0.423) \\
0.116^{* * *} \\
(0.040)\end{array}$ & $\begin{array}{l}0.852^{*} \\
(0.428) \\
0.106^{* *} \\
(0.042)\end{array}$ \\
\hline $\begin{array}{l}\text { Income Share } \\
\text { Top }\end{array}$ & & $\begin{array}{l}-0.067^{* *} \\
(0.027)\end{array}$ & $\begin{array}{l}-0.032 \\
(0.032)\end{array}$ & $\begin{array}{l}-0.114^{* * *} \\
(0.034)\end{array}$ & $\begin{array}{l}-0.055^{*} \\
(0.030)\end{array}$ & $\begin{array}{l}-0.028 \\
(0.025)\end{array}$ & $\begin{array}{l}-0.044 \\
(0.029)\end{array}$ & $\begin{array}{l}-0.052^{*} \\
(0.028)\end{array}$ \\
\hline $\begin{array}{l}\text { Income Share } \\
\text { Ratio }\end{array}$ & & $\begin{array}{l}0.155 \\
(0.096)\end{array}$ & $\begin{array}{l}0.174^{* *} \\
(0.065)\end{array}$ & $\begin{array}{l}-0.271^{* * *} \\
(0.060)\end{array}$ & $\begin{array}{l}0.149^{*} \\
(0.088)\end{array}$ & $\begin{array}{l}0.139^{*} \\
(0.081)\end{array}$ & $\begin{array}{l}0.151^{*} \\
(0.084)\end{array}$ & $\begin{array}{l}0.145 \\
(0.087)\end{array}$ \\
\hline Theil index & & $\begin{array}{l}0.210^{* * *} \\
(0.036)\end{array}$ & $\begin{array}{l}0.214^{* * *} \\
(0.033)\end{array}$ & & $\begin{array}{l}0.221^{* * *} \\
(0.042)\end{array}$ & $\begin{array}{l}0.185^{* * *} \\
(0.036)\end{array}$ & $\begin{array}{l}0.221^{* * *} \\
(0.041)\end{array}$ & $\begin{array}{l}0.190^{* * *} \\
(0.038)\end{array}$ \\
\hline Developed & & $\begin{array}{l}0.004 \\
(0.034)\end{array}$ & & & $\begin{array}{l}0.026 \\
(0.036)\end{array}$ & $\begin{array}{l}0.016 \\
(0.034)\end{array}$ & $\begin{array}{l}0.007 \\
(0.035)\end{array}$ & $\begin{array}{l}0.011 \\
(0.035)\end{array}$ \\
\hline Unpublished & & $\begin{array}{l}0.018 \\
(0.019)\end{array}$ & $\begin{array}{l}0.039 \\
(0.023)\end{array}$ & $\begin{array}{l}0.020 \\
(0.042)\end{array}$ & $\begin{array}{l}0.021 \\
(0.022)\end{array}$ & $\begin{array}{l}0.025 \\
(0.025)\end{array}$ & $\begin{array}{l}0.021 \\
(0.024)\end{array}$ & $\begin{array}{l}0.024 \\
(0.025)\end{array}$ \\
\hline Year data & & $\begin{array}{l}0.000 \\
(0.002)\end{array}$ & $\begin{array}{l}-0.001 \\
(0.003)\end{array}$ & $\begin{array}{l}-0.001 \\
(0.005)\end{array}$ & $\begin{array}{l}0.000 \\
(0.003)\end{array}$ & $\begin{array}{l}-0.001 \\
(0.003)\end{array}$ & $\begin{array}{l}-0.002 \\
(0.003)\end{array}$ & $\begin{array}{l}-0.001 \\
(0.003)\end{array}$ \\
\hline OLS & & $\begin{array}{l}-0.059^{* *} \\
(0.025)\end{array}$ & $\begin{array}{l}-0.067^{* *} \\
(0.025)\end{array}$ & $\begin{array}{l}-0.026 \\
(0.045)\end{array}$ & $\begin{array}{l}-0.061^{* *} \\
(0.028)\end{array}$ & $\begin{array}{l}-0.097^{* * *} \\
(0.034)\end{array}$ & $\begin{array}{l}-0.077^{* *} \\
(0.031)\end{array}$ & $\begin{array}{l}-0.081^{* * *} \\
(0.031)\end{array}$ \\
\hline LAC & & $\begin{array}{l}-0.104^{* * *} \\
(0.034)\end{array}$ & $\begin{array}{l}-0.331^{* * *} \\
(0.098)\end{array}$ & $\begin{array}{l}-0.151^{*} \\
(0.085)\end{array}$ & & $\begin{array}{l}-0.156^{* *} \\
(0.066)\end{array}$ & $\begin{array}{l}-0.241^{* * *} \\
(0.075)\end{array}$ & $\begin{array}{l}-0.142 \\
(0.106)\end{array}$ \\
\hline SSA & & $\begin{array}{l}0.017 \\
(0.033)\end{array}$ & $\begin{array}{l}0.106^{* *} \\
(0.049)\end{array}$ & $\begin{array}{l}0.116 \\
(0.105)\end{array}$ & $\begin{array}{l}0.039 \\
(0.050)\end{array}$ & & $\begin{array}{l}0.063 \\
(0.043)\end{array}$ & $\begin{array}{l}0.024 \\
(0.053)\end{array}$ \\
\hline SA & & $\begin{array}{l}-0.008 \\
(0.070)\end{array}$ & $\begin{array}{l}0.196^{* *} \\
(0.095)\end{array}$ & $\begin{array}{l}-0.028 \\
(0.083)\end{array}$ & $\begin{array}{l}0.443^{* * *} \\
(0.067)\end{array}$ & & $\begin{array}{l}0.123 \\
(0.080)\end{array}$ & $\begin{array}{l}0.099 \\
(0.065)\end{array}$ \\
\hline EAP & & $\begin{array}{l}-0.040 \\
(0.053)\end{array}$ & & $\begin{array}{l}0.093 \\
(0.071)\end{array}$ & $\begin{array}{l}-0.536^{* * *} \\
(0.074)\end{array}$ & & & $\begin{array}{l}0.003 \\
(0.087)\end{array}$ \\
\hline MENA & & $\begin{array}{l}0.064 \\
(0.049)\end{array}$ & $\begin{array}{l}0.085 \\
(0.101)\end{array}$ & $\begin{array}{l}-0.018 \\
(0.058)\end{array}$ & $\begin{array}{l}0.045 \\
(0.057)\end{array}$ & $\begin{array}{l}-0.001 \\
(0.095)\end{array}$ & $\begin{array}{l}0.070 \\
(0.043)\end{array}$ & \\
\hline EECA & & $\begin{array}{l}-0.012 \\
(0.021)\end{array}$ & $\begin{array}{l}0.007 \\
(0.031)\end{array}$ & $\begin{array}{l}-0.053 \\
(0.071)\end{array}$ & $\begin{array}{l}0.009 \\
(0.024)\end{array}$ & $\begin{array}{l}0.005 \\
(0.025)\end{array}$ & $\begin{array}{l}0.004 \\
(0.028)\end{array}$ & $\begin{array}{l}0.002 \\
(0.026)\end{array}$ \\
\hline Tax & & $\begin{array}{l}0.044 \\
(0.031)\end{array}$ & $\begin{array}{l}0.070 \\
(0.047)\end{array}$ & $\begin{array}{l}-0.014 \\
(0.036)\end{array}$ & $\begin{array}{l}0.052 \\
(0.032)\end{array}$ & $\begin{array}{l}0.091 \\
(0.054)\end{array}$ & $\begin{array}{l}0.085 \\
(0.052)\end{array}$ & $\begin{array}{l}0.086 \\
(0.053)\end{array}$ \\
\hline Trade & & $\begin{array}{l}0.120^{* * *} \\
(0.041)\end{array}$ & $\begin{array}{l}0.011 \\
(0.060)\end{array}$ & $\begin{array}{l}0.103 \\
(0.106)\end{array}$ & $\begin{array}{l}0.099^{*} \\
(0.051)\end{array}$ & $\begin{array}{l}0.114^{*} \\
(0.057)\end{array}$ & $\begin{array}{l}0.104^{*} \\
(0.059)\end{array}$ & $\begin{array}{l}0.128^{* *} \\
(0.058)\end{array}$ \\
\hline Governance & & $\begin{array}{l}0.031^{*} \\
(0.018)\end{array}$ & $\begin{array}{l}0.051^{* *} \\
(0.024)\end{array}$ & $\begin{array}{l}0.085^{* *} \\
(0.041)\end{array}$ & $\begin{array}{l}0.031 \\
(0.019)\end{array}$ & $\begin{array}{l}0.041^{*} \\
(0.024)\end{array}$ & $\begin{array}{l}0.039^{*} \\
(0.022)\end{array}$ & $\begin{array}{l}0.040^{*} \\
(0.023)\end{array}$ \\
\hline Inflation & & $\begin{array}{l}-0.081^{* * *} \\
(0.020)\end{array}$ & $\begin{array}{l}-0.075^{* * *} \\
(0.021)\end{array}$ & $\begin{array}{l}-0.044 \\
(0.037)\end{array}$ & $\begin{array}{l}-0.080^{* * *} \\
(0.023)\end{array}$ & $\begin{array}{l}-0.099^{* * *} \\
(0.027)\end{array}$ & $\begin{array}{l}-0.095^{* * *} \\
(0.026)\end{array}$ & $\begin{array}{l}-0.099^{* * *} \\
(0.026)\end{array}$ \\
\hline Population & & $\begin{array}{l}-0.041 \\
(0.027)\end{array}$ & $\begin{array}{l}-0.061^{*} \\
(0.036)\end{array}$ & $\begin{array}{l}-0.096^{*} \\
(0.053)\end{array}$ & $\begin{array}{l}-0.034 \\
(0.026)\end{array}$ & $\begin{array}{l}-0.061^{*} \\
(0.035)\end{array}$ & $\begin{array}{l}-0.063^{*} \\
(0.035)\end{array}$ & $\begin{array}{l}-0.059^{*} \\
(0.033)\end{array}$ \\
\hline Education & & $\begin{array}{l}0.009 \\
(0.023)\end{array}$ & $\begin{array}{l}0.051^{*} \\
(0.029)\end{array}$ & $\begin{array}{l}-0.035 \\
(0.041)\end{array}$ & $\begin{array}{l}0.005 \\
(0.025)\end{array}$ & $\begin{array}{l}0.025 \\
(0.029)\end{array}$ & $\begin{array}{l}0.022 \\
(0.029)\end{array}$ & $\begin{array}{l}0.020 \\
(0.030)\end{array}$ \\
\hline Health & & $\begin{array}{l}-0.002 \\
(0.029)\end{array}$ & $\begin{array}{l}-0.126^{* * *} \\
(0.041)\end{array}$ & $\begin{array}{l}0.138^{*} \\
(0.072)\end{array}$ & $\begin{array}{l}-0.025 \\
(0.031)\end{array}$ & $\begin{array}{l}-0.066 \\
(0.042)\end{array}$ & $\begin{array}{l}-0.052 \\
(0.042)\end{array}$ & $\begin{array}{l}-0.055 \\
(0.042)\end{array}$ \\
\hline
\end{tabular}




\begin{tabular}{|c|c|c|c|c|c|c|c|c|}
\hline $\begin{array}{l}\text { Education } \\
\text { spending }\end{array}$ & & $\begin{array}{l}0.008 \\
(0.032)\end{array}$ & $\begin{array}{l}-0.038 \\
(0.035)\end{array}$ & $\begin{array}{l}0.043 \\
(0.056)\end{array}$ & $\begin{array}{l}-0.018 \\
(0.032)\end{array}$ & $\begin{array}{l}-0.000 \\
(0.034)\end{array}$ & $\begin{array}{l}0.014 \\
(0.036)\end{array}$ & $\begin{array}{l}0.014 \\
(0.036)\end{array}$ \\
\hline $\begin{array}{l}\text { Health \& } \\
\text { Education } \\
\text { spending }\end{array}$ & & $\begin{array}{l}0.233^{* * *} \\
(0.036)\end{array}$ & & $\begin{array}{l}0.268^{* * *} \\
(0.064)\end{array}$ & $\begin{array}{l}0.219^{* * *} \\
(0.042)\end{array}$ & & & \\
\hline $\begin{array}{l}\text { Social welfare } \\
\text { spending }\end{array}$ & & $\begin{array}{l}-0.052 \\
(0.034)\end{array}$ & $\begin{array}{l}-0.157^{* * *} \\
(0.049)\end{array}$ & $\begin{array}{l}0.096 \\
(0.076)\end{array}$ & $\begin{array}{l}-0.060^{*} \\
(0.035)\end{array}$ & $\begin{array}{l}-0.117^{* *} \\
(0.047)\end{array}$ & $\begin{array}{l}-0.109^{* *} \\
(0.048)\end{array}$ & $\begin{array}{l}-0.105^{* *} \\
(0.048)\end{array}$ \\
\hline $\begin{array}{l}\text { Military } \\
\text { spending }\end{array}$ & & $\begin{array}{l}0.093^{*} \\
(0.052)\end{array}$ & $\begin{array}{l}0.074 \\
(0.053)\end{array}$ & $\begin{array}{l}0.171^{* * *} \\
(0.055)\end{array}$ & $\begin{array}{l}0.113^{*} \\
(0.057)\end{array}$ & $\begin{array}{l}0.136^{* *} \\
(0.055)\end{array}$ & $\begin{array}{l}0.153^{* *} \\
(0.060)\end{array}$ & $\begin{array}{l}0.159^{* * *} \\
(0.059)\end{array}$ \\
\hline $\begin{array}{l}\text { Housing } \\
\text { spending }\end{array}$ & & $\begin{array}{l}0.013 \\
(0.029)\end{array}$ & $\begin{array}{l}-0.074^{*} \\
(0.044)\end{array}$ & & $\begin{array}{l}-0.008 \\
(0.031)\end{array}$ & $\begin{array}{l}-0.036 \\
(0.041)\end{array}$ & $\begin{array}{l}-0.019 \\
(0.039)\end{array}$ & $\begin{array}{l}-0.024 \\
(0.041)\end{array}$ \\
\hline $\begin{array}{l}\text { Social } \\
\text { spending } \\
\text { (general) }\end{array}$ & & $\begin{array}{l}-0.095^{* *} \\
(0.044)\end{array}$ & $\begin{array}{l}-0.154 \\
(0.123)\end{array}$ & $\begin{array}{l}-0.019 \\
(0.074)\end{array}$ & $\begin{array}{l}-0.105^{* *} \\
(0.051)\end{array}$ & $\begin{array}{l}0.058 \\
(0.040)\end{array}$ & $\begin{array}{l}-0.130 \\
(0.140)\end{array}$ & $\begin{array}{l}0.049 \\
(0.045)\end{array}$ \\
\hline $\begin{array}{l}\text { Consumption } \\
\text { spending }\end{array}$ & & $\begin{array}{l}-0.019 \\
(0.025)\end{array}$ & $\begin{array}{l}-0.090^{* * *} \\
(0.032)\end{array}$ & $\begin{array}{l}0.027 \\
(0.046)\end{array}$ & $\begin{array}{l}-0.033 \\
(0.029)\end{array}$ & $\begin{array}{l}-0.042 \\
(0.030)\end{array}$ & $\begin{array}{l}-0.048 \\
(0.031)\end{array}$ & $\begin{array}{l}-0.035 \\
(0.030)\end{array}$ \\
\hline $\begin{array}{l}\text { Other } \\
\text { spending }\end{array}$ & & $\begin{array}{l}0.036 \\
(0.032)\end{array}$ & $\begin{array}{l}-0.065 \\
(0.053)\end{array}$ & $\begin{array}{l}0.039 \\
(0.059)\end{array}$ & $\begin{array}{l}0.024 \\
(0.034)\end{array}$ & $\begin{array}{l}-0.022 \\
(0.053)\end{array}$ & $\begin{array}{l}-0.015 \\
(0.053)\end{array}$ & $\begin{array}{l}-0.009 \\
(0.053)\end{array}$ \\
\hline Constant & $\begin{array}{l}-0.111^{* * *} \\
(0.021)\end{array}$ & $\begin{array}{l}-0.013 \\
(0.049)\end{array}$ & $\begin{array}{l}-0.166^{*} \\
(0.097)\end{array}$ & $\begin{array}{l}0.029 \\
(0.123)\end{array}$ & $\begin{array}{l}-0.136^{* * *} \\
(0.032)\end{array}$ & $\begin{array}{l}0.036 \\
(0.097)\end{array}$ & $\begin{array}{l}-0.113 \\
(0.090)\end{array}$ & $\begin{array}{l}-0.090 \\
(0.085)\end{array}$ \\
\hline$N$ & 943 & 943 & 572 & 371 & 798 & 687 & 738 & 743 \\
\hline$R^{2}$ & 0.027 & 0.274 & 0.392 & 0.317 & 0.276 & 0.333 & 0.323 & 0.337 \\
\hline
\end{tabular}

Notes: The dependent variable in all regressions is the partial correlation coefficient. Standard errors are reported in parentheses. All regressions use cluster standard errors to adjust for data dependence, i.e. multiple estimates per study. Outliers have been removed for all regressions. All columns use weighted least squares using inverse variance weights.

${ }^{*} p<0.1,{ }^{* *} p<0.05,{ }^{* * *} p<0.01$.

Finally, there are some similarities between the regressions presented in Table 3 and some of the subgroup analyses presented in Table 5. For example, the coefficient for income share bottom is consistently positive and statistically significant, indicating again that studies using this measure tend to report a less negative (or more positive) relationship between government spending and income inequality. Similarly, OLS is consistently negative and significant across 4 subgroup comparisons implying that studies using this estimation method are, on average, reporting a larger negative (or smaller positive) relationship between government spending and income inequality.

Note however that there is a marked difference between the results for the different measures of spending, depending on whether developed countries are included in the sample (regressions 3 and 4). In particular, the positive and statistically coefficient on military spending is observed only for samples excluding developed countries, while the negative and statistically coefficient on social welfare spending is only observed for samples including developed countries. Furthermore, while the coefficient on health spending is negative and statistically significant for samples including developed countries, it is positive and statistically significant for samples excluding them. These 
results suggest that government spending on social sectors (e.g. health, education, social welfare) has a greater redistributive impact in developed countries than in developing countries.

As mentioned above, we also conducted further robustness checks using different approaches to addressing multiple dependent estimates per study. Online Appendix Table A4.1. presents the results of the different weighting schemes that are often used to deal with biases due to data dependence.

\section{Is there an association between government spending and income inequality?}

The results in Tables 3-5 show that both the size and direction of the estimated relationship between government spending and income inequality are affected by a range of factors, including the country composition of the sample, the control variables included in the analysis, the analytical approach used, and the measure of government spending used. This makes it difficult to answer the question of whether or not there is - on average - a strong association between government spending and income inequality. However, we are able to make some progress towards this question by calculating the average (or predicted) relationship between government spending and income inequality implied by the results in Tables 3-5, for a certain set of values of the moderator variables. This is done in Table 6.

Panel A of Table 6 shows the average relationship between the different measures of government spending and different measures of inequality predicted by the results in Regression 3 of Table 3; Panel B then does the same using the results in Regression 5. In each case, we consider a study that is published, uses a more robust non-OLS analytical approach, includes all developing country regions but not developed countries in the sample, uses a period of time centred on 1986, and includes all six control variables in the analysis (e.g. governance, inflation, education, and so on). At least for this set of moderator variables, the average relationship is negative in most cases, particularly for the Gini coefficient and the top income share, and when using the Regression 5 results. In these cases, the negative relationship tends to be largest in magnitude for social welfare spending and general social spending, which includes health and education as well as social welfare. Not surprisingly perhaps, there is no evidence of a negative relationship in the case of military spending. However, the relationship is also statistically insignificant for all measures of government spending when using the bottom income share, and is often positive and statistically significant when using the ratio of income shares. This suggests that the redistributive impact of government spending has not extended to the entire income distribution, but has instead been concentrated more towards middle income groups.

The results in Table 6 refer of course only to one particular set of moderator variables. They are also based only on the pooled results in Table 3, and as we have seen there are some differences in results by sub-group. Nevertheless, the results do show at least some evidence of a statistically significant negative relationship between most categories of government spending and income inequality, which appears to be stronger for social spending, and for the Gini coefficient and top income share measures of inequality. In terms of the strength of association, it has been suggested that a partial correlation coefficient of less than 0.07 in absolute terms can be considered small, with 0.17 or above considered to be moderate, and 0.33 or above large (Doucouliagos 2011, Abdullah et al 2015). This is in line with what Cohen (1988: 115) suggests who argues that for partial correlation 
coefficients, the effects are considered to be small when $r=0.1$, medium when $r=0.3$ and large when $r=0.5$. Judging by these guidelines therefore, the results in Table 6 imply a small to moderate negative relationship between government spending and income inequality.

Table 6. Predicted (average) relationship between government spending and income inequality

\begin{tabular}{|c|c|c|c|c|}
\hline \multirow[b]{2}{*}{ Measure of spending } & \multicolumn{4}{|c|}{ Measure of inequality } \\
\hline & Gini & $\begin{array}{l}\text { Income share } \\
\text { bottom }\end{array}$ & $\begin{array}{l}\text { Income share } \\
\text { top }\end{array}$ & $\begin{array}{l}\text { Income share } \\
\text { ratio }\end{array}$ \\
\hline \multicolumn{5}{|l|}{ A. $^{+}$} \\
\hline Total spending & -0.014 & 0.083 & -0.080 & 0.141 \\
\hline Health spending & -0.015 & 0.082 & -0.082 & 0.139 \\
\hline Education spending & -0.006 & 0.091 & -0.072 & 0.149 \\
\hline Social welfare spending & -0.066 & 0.031 & $-0.132^{*}$ & 0.089 \\
\hline Military spending & 0.080 & 0.177 & 0.013 & $0.234^{*}$ \\
\hline Social spending (general) & -0.109 & -0.012 & $-0.175^{* *}$ & 0.046 \\
\hline Consumption spending & -0.033 & 0.064 & -0.100 & 0.121 \\
\hline Other spending & 0.022 & 0.119 & -0.044 & 0.177 \\
\hline \multicolumn{5}{|l|}{ B. $\#$} \\
\hline Total spending & $-0.125^{* *}$ & -0.002 & $-0.207^{* * *}$ & $0.132^{* *}$ \\
\hline Health spending & $-0.141^{* *}$ & -0.019 & $-0.223^{* * *}$ & $0.115^{*}$ \\
\hline Education spending & $-0.130^{* *}$ & -0.007 & $-0.212^{* * *}$ & $0.127^{* *}$ \\
\hline Social welfare spending & $-0.185^{* * *}$ & -0.063 & $-0.267^{* * *}$ & 0.071 \\
\hline Military spending & -0.019 & 0.103 & -0.102 & $0.237^{* * *}$ \\
\hline Social spending (general) & $-0.203^{* * *}$ & -0.081 & $-0.285^{* * *}$ & 0.054 \\
\hline Consumption spending & $-0.161^{* * *}$ & -0.039 & $-0.243^{* * *}$ & 0.095 \\
\hline Other spending & -0.087 & 0.035 & $-0.169^{* * *}$ & $0.169^{* * *}$ \\
\hline
\end{tabular}

Notes: +Based on regression 3 in Table 3; "based on regression 5 in Table 3. The following values of all moderator variables: standard error=0; unpublished=0; yeardata=0; OLS=0; LAC, SSA, SA, EAP, MENA, EECA all equal to 1; Tax, Trade, Governance, Inflation, Population, Education all equal to 1 . We do not include the results for the health and education or housing spending categories, or the Theil index, given the low number of observations for these variables.

${ }^{*} p<0.1,{ }^{* *} p<0.05,{ }^{* * *} p<0.01$

\section{Conclusion}

The issue of inequality has been a key issue in international development for several decades now. 
Although there are many ways of addressing inequality, choices with regard to the level and composition of government spending are frequently cited as a key area, and a large body of literature has emerged which investigates the effects of government spending on income inequality. The meta-regression analysis presented in this paper, based on a total of 84 separate studies containing over 900 estimates, shows that both size and direction of the relationship between government spending and income inequality are affected by a range of factors. The following paragraphs summarise our key findings and highlight the implications, both for our understanding of the research field and for policy.

First, we find that the estimated relationship between government spending and income inequality depends on the measure of inequality used. In comparison with the Gini coefficient, the relationship tends to be stronger (more negative) when focusing on the share of the richest $10 \%$ or $20 \%$ in national income, and weaker (less negative) when focusing on the share of the poorest $20 \%$ or $40 \%$. This is an important finding for policy, since it suggests that the redistributive impact of government spending has not extended to the entire income distribution, but has instead been concentrated in the upper half of the distribution, towards middle income groups. This is consistent with the argument that the benefits of government spending are often captured by the middle class, for political economy reasons (Tanzi 1974, Milanovic 1994, Alesina 1998, Davoodi et al 2003). In terms of further research, it would be better if studies use a wider range of inequality measures, rather than relying solely on the Gini coefficient, which is much more sensitive to income changes in the middle part of the distribution than it is to changes at the top or bottom (Atkinson 1970).

Second, on the whole we find little evidence that the period of time covered by the samples used for estimation, or the inclusion of developed countries, makes a big difference to the results. This is an important finding for research, because econometric studies typically use the largest possible time period, and include both developed and developing countries, in order to increase sample size; our results on the whole provide no indication that this affects the results substantially. The main exception occurs when focusing specifically on social welfare spending, where estimates using more recent data show a more negative relationship with income inequality. One possible explanation is a general tendency for expenditure in this area to become more progressive over time, which could be due to better targeting associated with the recent expansion of conditional cash transfer programmes (Lindert et al 2006, Bastagli et al 2012). However, social welfare spending still has a much weaker (less negative) relationship with income inequality when developed countries are excluded from the analysis, suggesting that targeting problems remain significant in many developing countries (Coady et al 2004, Goni et al 2011).

Third, we find some evidence that studies using ordinary least squares (OLS) as an estimation method find a larger negative (or smaller positive) relationship between government spending and income inequality. This finding is not robust across all specifications, but what evidence there is indicates that studies relying on OLS have had a tendency to overestimate the contribution of government spending to the reduction of inequality, compared with more robust analytical approaches such as panel data methods and instrumental variables (IV) estimation. We did attempt a risk of bias assessment of the included studies, employing an adapted version of the risk of bias tool developed by Duvendack et al (2011 and 2012). ${ }^{\mathrm{xv}}$ According to this tool the studies using OLS as an estimation method were classified as medium risk of bias, suggesting that more robust analytical approaches such as panel data methods and instrumental variables (IV) estimations would have 
lowered the risk of bias. We should note, however, that this tool was developed for the purpose of micro-econometric studies and thus not entirely appropriate for the cross-country regressions which are dominant in this case. Further work is required to develop more convincing approaches to assessing the quality of studies included in systematic reviews as well as meta-regressions.

Fourth, we find some evidence of publication bias. This is another important finding, because unless this is corrected for in some way, publication bias can lead to significant errors in attempts to summarise empirical knowledge on a given issue (Stanley and Doucouliagos 2012). In this case however, the amount of bias does not appear to be large, and the coefficient on the standard error term is not statistically significant in all of our robustness checks. What evidence there is suggests that negative estimates of the relationship between government spending and income inequality are being under-reported in the literature. It is difficult to say precisely what might be driving the publication bias in this case. One possible explanation is that it is due to 'polishing' - in other words, the tendency for researchers and editors to report and publish results that are statistically significant (Doucouliagos and Paldam 2008). Another possible explanation is that researchers themselves are reluctant to report negative relationships, perhaps because of ideological persuasion (e.g. a belief in limited government involvement in the economy), or because funding institutions are pre-disposed towards this view. ${ }^{\text {.vi }}$ It is notable however that when we focus specifically on social welfare spending, the direction of publication bias is reversed: in this case, positive estimates of the relationship appear to be under-reported in the literature. This could be because positive estimates in this case conflict more strongly with prior expectations.

Finally, in terms of the overall association between government spending and income inequality, after controlling for publication bias, we find that the answer depends very much on the type of spending being considered and the measure of inequality. The results show some evidence of a moderate negative relationship between government spending and income inequality, which is strongest for social welfare and other social spending, and when using the Gini coefficient or the top income share as the measure of inequality. It is important to recognize however that both the size and direction of the estimated relationship is affected by a range of factors. This makes it difficult to say whether or not there is on average a strong association between any particular type of government spending and income inequality. Although we have in this study been able to identify some of the factors influencing the size and direction of the relationship, it is clear that there is much heterogeneity left to explain.

We end by highlighting some of the limitations of this study and some potential directions for further work. On the one hand, we have shown that most of our main results are robust to a range of different robustness checks, including different ways of treating outliers, different possible weighting schemes, and different measures of inequality. It is clear however that different ways of dealing with multiple estimates per study, including the use of study-level fixed effects, can lead to more different results, at least in this case. We argue that this is an important area for further research. On the other hand, the analysis in this paper focuses only on the effects of government spending, which is only one aspect of fiscal policy. It would be of equal interest to examine the relationship between taxation and income inequality, which has been examined in a large number of econometric studies but not yet analysed using MRA. This is another potential area for further research. 


\section{References}

Abdullah, A., Doucouliagos, H. and Manning, E. (2015). Does education reduce income inequality? A meta-regression analysis. Journal of Economic Surveys, 29, 301-316.

Alesina, A. (1998). The political economy of macroeconomic stabilisations and income inequality: myths and reality. In Tanzi, V. and Chu, K. (eds), Income Distribution and High-Quality Growth. MIT Press, London.

Alesina, A. and Perotti, R. (1996). Income distribution, political instability, and investment, European Economic Review, 40, 1203-1228.

Anderson, E., D'Orey, M.J., Duvendack, M. and Esposito, L. (2015). The impact of government policies on income inequality and the translation of growth into income poverty reduction: protocol for two systematic reviews. Journal of Development Effectiveness, 7(4), 484-498.

Atkinson, A. (1970). On the measurement of inequality. Journal of Economic Theory, 2, 244-263.

Barber J. G. (2001). Relative misery and youth suicide. Australian Journal of Psychiatry, 35, 49-57.

Bastagli, F., Coady, D. and Gupta, S. (2012). Income inequality and fiscal policy. IMF Staff Discussion Note 12/08, International Monetary Fund, Washington D.C.

Bastagli, F., Coady, D. and Gupta, S. (2015). Fiscal redistribution in developing countries: overview of policy issues and options. In Clements, B., Mooij, R., Gupta, S. and Keen, M. (eds), Inequality and Fiscal Policy. International Monetary Fund, Washington D.C.

Benabou, R. (2000). Unequal societies: income distribution and the social contract. American Economic Review, 90, 96-129.

Bird, R. and Zolt, E. (2005). Redistribution via taxation: the limited role of the personal income tax in developing countries. UCLA Law Review, 52, 1627-1695.

Borenstein, M., Hedges, L.V., Higgins J.P.T. and Rothstein, H.R. (2009). Introduction to Meta-Analysis, Wiley, Chichester.

Bulif, A. (1998). Income Inequality: Does inflation matter? IMF Working Paper WP/98/7, January.

Campbell Collaboration (2012). Systematic Reviews in International Development: Key Online Databases. Available at: http://www.campbellcollaboration.org./artman2/uploads/1/Database_Guide_for_SRs_in_Int ernational_Development_1.pdf

Chu, K., Davoodi, H. and Gupta, S. (2000). Income distribution and tax and government spending policies in developing countries. IMF Working Paper 00/62, International Monetary Fund, Washington D.C.

Clark, A.E., Frijters, P. and Shields, M.A. (2008). Relative income, happiness, and utility: an explanation for the Easterlin paradox and other puzzles. Journal of Economic Literature, 46, 95-144. 
Claus, I., Martinez-Vazquez, J. and Vulovic, V. (2012). Government fiscal policies and redistribution in Asian countries. ADB Economics Working Paper Series 310, Asian Development Bank, Manila.

Coady, D., Grosh, M. and Hoddinott, J. (2006). Targeting of Transfers in Developing Countries. World Bank, Washington D.C.

Cohen, J. (1988). Statistical Power Analysis for the Behavioural Sciences. 2nd ed. Hillsdale, NJ: Erlbaum Associates.

Davoodi, H., Tiongson, E. and Asawanuchit, S. (2003). How useful are benefit incidence analyses of public expenditure and health spending? IMF Working Paper 03/227, International Monetary Fund, Washington D.C.

De Mello, L. and Tiongson, E. (2006). Income inequality and redistributive government spending. Public Finance Review, 34(3), 282-305.

Dollar, D. and Kraay, A. (2002). Growth is good for the poor. Journal of Economic Growth, 7(3), 195225.

Dollar, D., Kleineberg, T. and Kraay, A. (2013). Growth is still good for the poor. Policy Research Working Paper 6568, World Bank, Washington D.C.

Doucouliagos, C. (2011). How large is large? Preliminary and relative guidelines for interpreting partial correlations in economics. Economic Series 2011_5. Australia: Faculty of Business and Law, School of Accounting, Economics and Finance, Deakin University.

Doucouliagos, C. and Paldam, M. (2008). Aid effectiveness on growth: a meta-study. European Journal of Political Economy, 24, 1-24.

Doucouliagos, C. and Paldam, M. (2009). The aid effectiveness literature: the sad results of 40 years of research. Journal of Economic Surveys, 23(3), 433-461.

Doucouliagos, C. and Paldam, M. (2014). Finally a breakthrough? The recent rise in the size of the estimates of aid effectiveness. Economics Working Papers 2014-07, Aarhus University, Denmark.

Duvendack, M., Palmer-Jones, R., Copestake, J. G., Hooper, L., Loke, Y. and Rao, N. (2011). "What is the Evidence of the Impact of Microfinance on the Well-being of Poor People?" London: EPPICentre, Social Science Research Unit, Institute of Education, University of London.

Duvendack, M., Hombrados, J., Palmer-Jones, R. and Waddington, H. (2012). Assessing 'What Works' in International Development: Meta-Analysis for Sophisticated Dummies. Journal of Development Effectiveness, 4(3), 456-471.

Easterlin, R.A. (1974). Does economic growth improve the human lot? Some empirical evidence. In: David, R., Reder, R. (Eds.), Nations and Households in Economic Growth: Essays in Honor of Moses Abramovitz, Academic Press, New York.

Easterly, W. and S. Fischer (2001). Inflation and the Poor. Journal of Money, Credit and Banking, 33 (2), 160-178. 
Egger, M.D., Smith, G., Schneider, M. and Minder, C. (1997). Bias in meta-analysis detected by a simple, graphical test. BMJ, 315, 629-634.

Eibner, C. E. and William N. E. (2005). Relative Deprivation, Poor Health Habits and Mortality, Journal of Human Resources, 40, 591-620.

Goni, E., Lopez, J.H. and Serven, L. (2011). Fiscal Redistribution and Income Inequality in Latin America. World Development, 39(9), 1558-1569.

Gravelle, H., and Sutton, M. (2009). Income, relative income, and self-reported health in Britain 1979-2000, Health Economics, 18, 125-145.

Hunter, J. and Schmidt, F. (2004). Methods of Meta-Analysis: Correcting Error and Bias in Research Findings. Sage Publications, London.

Iršová, Z. and Havránek, T. (2013). Determinants of Horizontal Spillovers from FDI: Evidence from a Large Meta-Analysis. World Development, 42, 1-15.

Josheski, D. (2011). Infrastructure investment and economic growth: a meta-regression analysis. Lambert Academic Publishing.

Leonard, de Linde M., Stanley, T.D. and Doucouliagos, H. (2014). Does the UK Minimum Wage Reduce Employment? A Meta-Regression Analysis. British Journal of Industrial Relations, 52(3), 499-520.

Lipsey, M. P. and Wilson, D. (2001). Practical Meta-Analysis. Sage Publications.

Lindert, K., Skoufias, E. and Shapiro, J. (2006). Redistributing Income to the Poor and the Rich: Public Transfers in Latin America and the Caribbean, SP Discussion Paper No. 0605, The World Bank, Washington D.C.

Lustig, N. (2011). Fiscal policy and income redistribution in Latin America: challenging the conventional wisdom. Working Paper 2011-227, Society for the Study of Economic Inequality.

Lustig, N. (2015). Inequality and fiscal redistribution in middle income countries: Brazil, Chile, Colombia, Indonesia, Mexico, Peru and South Africa. Working Paper 410, Center for Global Development, Washington D.C.

Lustig, N., Lopez-Calva, L. and Ortiz-Juarez, E. (2013). Declining Inequality in Latin America in the 2000s: The Cases of Argentina, Brazil, and Mexico. World Development, 44, 129-141.

Luttmer, E. (2005). Neighbours as negatives: Relative earnings and wellbeing. Quarterly Journal of Economics, 120, 963-1002.

Mahon, J. (2012). Tax incidence and tax reforms in Latin America. Woodrow Wilson Center, Williams College, Massachusetts.

Martinez-Vasquez, J., Vulovic, V. and Moreno-Dodson, B. (2012). The impact of tax and expenditure policies on income distribution: evidence from a large panel of countries. Review of Public Economics, 200(4), 95-130. 
Meltzer, A. and Richard, S. (1981). A rational theory of the size of government. Public Choice, 41, 403-418.

Milanovic, B. (2000). Do more unequal societies redistribute more? Does the median voter hypothesis hold? European Journal of Political Economy, 16, 367-410.

Moeltner, K. and Rosenberger, R.S. (2008). Predicting Resource Policy Outcomes via MetaRegression: Data Space, Model Space, and the Quest for 'Optimal Scope'. The B.E. Journal of Economic Analysis \& Policy, 8(1), 1935-1682.

Mosley, P., Hudson, J. and Verschoor, A. (2004). Aid, poverty reduction and the 'new conditionality'. Economic Journal, 113, F217-F243.

Ostry, J.D., Berg, A. and Tsangarides, C. G. (2014). Redistribution, Inequality and Growth. IMF Staff Discussion note. SDN/14/02.

Persson, T. and Tabellini, G. (1994). Is inequality harmful to growth? Theory and evidence. American Economic Review, 84, 600-621.

Ravallion, M. (1997). Can high-inequality developing countries escape absolute poverty? Economics Letters, 56, 51-57.

Rhee, C., Zhuang, J., Kanbur, R. and Felipe, J. (2014). Confronting Asia's rising inequality: policy options. In Kanbur, R., Rhee, C. and Zhuang, J. (eds), Inequality in Asia and the Pacific: Trends, Drivers and Policy Implications. Routledge: London.

Stanley, T.D. (2005). Beyond publication selection. Journal of Economic Surveys, 19, 309-345.

Stanley, T.D. (2008). Meta-regression methods for detecting and estimating empirical effects in the presence of publication bias. Oxford Bulletin of Economics and Statistics, 70, 103-127.

Stanley, T.D. and Doucouliagos, H. (2012). Meta-regression Analysis in Economics and Business, Routledge, Abingdon.

Stanley, T.D., Doucouliagos, H., Giles, M., Heckemeyer, J.H., Johnston, R.J., Laroche, P., Pugh, G., Nelson, J., Paldam, M., Poot, J., Rosenberger, R. and Rost, K. (2013). Meta-analysis of economics research reporting guidelines. Journal of Economic Surveys, 27(2), 390-394.

Stanley, T.D. and Doucouliagos, H. (2013). Better than Random: Weighted Least Squares MetaRegression Analysis. Deakin University, Economics Working Paper Series SWP 2013/2, July. Available at: http://www.deakin.edu.au/buslaw/aef/workingpapers/papers/2013 2.pdf

Stanley, T.D. and Doucouliagos, H. (forthcoming, 2016). Neither Fixed nor Random: Weighted Least Squares Meta-Regression Analysis. Research Synthesis Methods, forthcoming 2016.

Stiglitz, J. (2013). The Price of Inequality. Penguin.

Subramanian, S. V. and I. Kawaki (2006). Being well and doing well: on the importance of income for health. International Journal of Social Welfare, 15, (Suppl. 1), S13-S22. 
Tanzi, V. (1974). Redistributing income through the budget in Latin America. Banca Nazionale del Lavoro Quarterly Review, 27(108), 65-87.

Veenstra, G. (2005). Social status and health: absolute deprivation or relative comparison, or both? Health Sociologic Review, 14, 121-134.

Wilkinson, R. and Pickett, K. (2009). The Spirit Level: Why More Equal Societies Almost Always Do Better. Allen Lane.

Williams, K. R. (1984). Economic Sources of Homicide: Reestimating the effects of Poverty and Inequality. American Sociologic Review, 49, 283-289.

World Bank (2005). World Development Report 2006: Equity and Development. Oxford University Press. 


\section{Notes}

'This paper is part of a wider systematic review entitled "What policies and interventions have been strongly associated with changes in in-country income inequality?" funded by DFID. A summary of the protocol for this review is provided by Anderson et al (2015); the full protocol is available here:

http://r4d.dfid.gov.uk/pdf/outputs/SystematicReviews/Income inequality 2014 Anderson protocol.pdf. The final report is forthcoming.

ii Some evidence in support of this argument has been found by Milanovic (2000) and Ostry et al (2014), although it has been challenged by other authors (e.g. Perotti 1996, Benabou 2000, de Mello and Tiongson 2006), who argue that governments in countries where inequality is high tend to redistribute less, because political power is firmly in control of higher income groups, who are able to resist any redistributive measures.

iii Note that evidence on the effects of government spending on income inequality is not restricted to econometric evidence; a large body of evidence also comes from fiscal incidence analysis (e.g. Goni et al 2011; Lustig 2011, 2015). In this paper however we are concerned only with synthesising results from the econometric literature.

iv There have, by contrast, been a number of systematic reviews of the evidence on the determinants of economic growth, including Doucouliagos and Paldam $(2008,2009,2014)$ on the effects of foreign aid, and Josheski (2011) on the effects of infrastructure investment.

$\checkmark$ We should note that the search strategy outlined in this section was developed for the wider systematic review that was commissioned and funded by DFID (see footnote 2), which looked at all types of government policies and their link to income inequality. The focus was therefore on a broader range of policy interventions, not just government spending.

vi Our strategy is to use $n=1$ to capture concepts such as 'distribution of income', 'inequality of income', as well as 'income distribution' and 'income inequality'.

vii The t-statistic was multiplied by -1 when the dependent variable referred to the income share of the poorest decile or quintile(s) or the average income of the poorest decile or quintile(s). This is because a rise in these variables corresponds to a fall in income inequality.

viii Note that when we refer to a "study" this could include two separate papers, e.g. an initial working paper followed by a published journal article, if the two papers clearly form part of the same research study. In such cases, we only include estimates from the earlier working paper if they differ from those contained in the published article.

ix Note that the standard error of the partial correlation coefficient is different from the standard error of the individual regression coefficients.

x Social welfare spending includes components such as pensions, social security, social protection, and other welfare spending. The social spending (general) category includes spending on education, health, housing and social welfare. Total government spending is used if the study refers to "total government spending", or just "government spending". Government consumption is used if the study refers specifically to government "consumption" expenditure. If the study refers to categories of government spending not covered by the other codes, (e.g. government investment spending or wage bill) it was coded under government spending others.

${ }^{x i}$ Note that for some studies we include estimates from an unpublished working paper as well as from a published journal article (see note viii above). In such cases, the former are coded as unpublished while the latter are coded as published, even though they are from the same study.

xii Note however that the results for the Theil index should be treated with caution, since we have only one estimate using this measure of inequality.

xiii This value was calculated by adding the coefficient on income share other to the constant, i.e. $-0.108+0.165$.

xiv Robust regressions are an alternative to least squares with the purpose to minimise the influence of any potential outliers. In other words, robust regressions can be considered to be a robustness check used to detect or minimise suspected outliers. 
${ }^{x v}$ As outlined in the protocol of the DFID funded systematic review of which this paper is a part; see Anderson et al (2015) for details.

xvi This is in fact the explanation favoured by Doucouliagos and Paldam $(2008,2009)$ to explain the evidence of publication bias in the aid effectiveness literature. They argue that the research community is reluctant to publish negative estimates of this relationship, partly because of researchers desire to be seen as supporting the 'do-good' activity of foreign aid, and partly because research is often funded by aid organisations. 